\title{
THE PROSPECTS FOR SELF-REGULATION OF FINANCIAL MARKETS: THE STATE REGULATOR'S INFLUENCE IN ON THE INCREASE
}

\author{
N.Polezhaeva
}

A comparative analysis of the existing model of financial market regulation and the model put forth by the Bank of Russia within the framework of the Draft Federal Law 'On Self-Regulating Organizations in the Field of Financial Markets' indicates that the Bank of Russia is creating a new system of regulating the activity of self-regulating organizations operating in Russia's financial markets, which significantly increases the powers of the state regulator. According to the Draft Law, the state regulator is to become free to unilaterally determine the scope of its own participation in the regulatory process. The unfettered discretion given to the state regulator may significantly undermine the interests of self-regulating organizations and their members, because the Draft Law fails to put forth any formal guarantees that the Bank of Russia should indeed permit such organizations to adequately participate in the process of setting standards and guidelines, or in monitoring the compliance therewith.

On 1 September 2013, the Federal Law 'On the Introduction of Alterations to Some Legislative Acts of the Russian Federation in Connection with the Transfer to the RF CB of the Authority to Regulate, Control and Supervise Financial Markets' ${ }^{1}$ came into effect. On that day, the powers formerly vested in one federal body, the Federal Financial Markets Service, were transferred to another such body, the Bank of Russia.

Even before the Federal Law came into force, the Bank of Russia had increased the scale of its interference in the activity of self-regulating organizations comprising financial institutions ${ }^{2}$, clearly aiming at boosting its role as state regulator. It should be noted in this connection that any substantial rise in the powers of state regulator vis-à-vis self-regulating organizations can have a negative effect on the activity of such organizations if they are deprived of any of the main components of self-regulation. These components are as follows: the right to set standards and guidelines for professional (or entrepreneurial) activity, and the right to monitor compliance with the said standards and guidelines ${ }^{3}$.

Similar trends can be detected in the Draft Federal Law 'On Self-Regulating Organizations in the Field of Financial Markets's developed by the Bank of Russia

1 Federal Law of 23 July 2013, No 251-FZ 'On the Introduction of Alterations to Some Legislative Acts of the Russian Federation in Connection with the Transfer to the Central Bank of the Russian Federation of the Authority to Regulate, Control and Supervise Financial Markets' // Sobranie zakonodatel'stva Rossiiskoi Federatsii [Collection of Legislation of the Russian Federation], 29 July 2013, No 30 (Part I), p. 4084.

2 Non-credit financial institutions and credit institutions operating in the securities market.

3 See item 1 , article 2 of the Federal Law of 1 December 2007, No 315-FZ 'On Self-Regulating Organizations' // Sobranie zakonodatel'stva Rossiiskoi Federatsii [Collection of Legislation of the Russian Federation], 3 December 2007, No 49, p. 6076.

4 See: http://www.nfa.ru/docs/zpsro.pdf. and submitted to the RF Government for consideration in $2013^{5}$.

Similarly to the framework law on self-regulating organizations adopted in $2007^{6}$, the CB's draft law sets some purely general principles of self-regulation in financial markets, irrespective of the type of one or other self-regulating organization.

It should be noted that, initially, the framework law on self-regulating had been developed exclusively as a law on self-regulating organizations operating in financial markets. However, as the framework law's developers had failed to coordinate it with the Bank of Russia and the Federal Financial Markets Service, some of Russia's financial markets were excluded from the sphere of application of that law?

One of the Draft Law's key ideas, which actually puts at risk the freedom of activity of self-regulating organizations, is expressed in its provisions that the function of setting standards and guidelines for self-regulating organizations should be subject to increased legislative regulation, and that the state regulator's authority with regard to these matters should be expanded (Articles 9 and 10).

The Draft Law submitted by the Bank of Russia requires that self-regulating organizations operating in financial markets will have to develop and approve

5 See N. A. Polezhaeva, Pravovoye regulirovanie deiatel'nosty smoreguliruemykh organizatsii professional'nykh uchastnikov rynka tsennykh bumag [Legal regulation of the activity of the selfregulating organizations of professional security market participants] // Zakon i pravo [Law and Justice], 2013, No 8, pp. 50-52. 6 Federal Law of 1 December 2007, No 315-FZ 'On Self-Regulating Organizations'.

7 See V. S. Pleskachevsky's presentation delivered on 19 March 2013 at the Third All-Russian Forum of Self-Regulating Organizations 'Self-Regulation in Russia: The Experience and Prospects of Development' held within the framework of the Russian Business Week 2013 (under the aegis of the Russian Union of Industrialists and Entrepreneurs). 
mandatory internal standards for self-regulating organizations, and also to develop, approve and coordinate with the Bank of Russia a set of mandatory basic standards uniform for all self-regulating organizations of the same type.

In order to be granted the status of self-regulating organization, a not-for-profit organization will be obliged to conform to the basic standards previously coordinated with the Bank of Russia. Also, such standards can become mandatory for all corresponding type financial institutions irrespective of whether or not they are members of the self-regulating organization.

The Bank of Russia intends to establish the list of internal and basic standards that a self-regulating organization will be obliged to develop and approve, and to determine the volume, the content and the form of the social relationships to be regulated.

The afore-mentioned standards should conform to both Russian legislation and the Bank of Russia's normative acts, the provisions of which are as yet unknown.

As a rule, existing financial legislation ${ }^{1}$ is silent on the issue of the state regulator's participation the process of developing and setting the afore-mentioned standards and guidelines, thus leaving these processes to the discretion of the organizations themselves.

It should be said that those participants in self-regulation that take part in the development of at least some of the standards and guidelines follow them more willingly than the standards and guidelines imposed on them from above.

Thus, for example, the model of self-regulation that operated in the US securities market prior to 2007 was characterized by the co-existence of two major selfregulating organizations: the New York Stock Exchange

1 Federal Law of 22 April 1996, No 39-FZ 'On the Securities Market' // Sobranie zakonodatel'stva Rossiiskoi Federatsii [Collection of Legislation of the Russian Federation], No 17, 22 April 1996, p. 1918; Federal Law of 29 November 2001 'On Investment Funds' // Sobranie zakonodatel'stva Rossiiskoi Federatsii [Collection of Legislation of the Russian Federation], 3 December 2001, No 49, p. 4562; Federal Law of 7 May 1988, No 75-FZ 'On Non-Governmental Pension Funds' // Sobranie zakonodatel'stva Rossiiskoi Federatsii [Collection of Legislation of the Russian Federation], No 19, 11 May 1998, p. 2071; RF Law of 27 November 1992, No 4015-1 'On the Organization of Insurance Affairs in the Russian Federation' // Rossiiskaia Gazeta [The Russian Gazette], No 6, 12 January 1993; Federal Law of 30 December 2004, No 215-FZ 'On Housing Savings Cooperatives' // Sobranie zakonodatel'stva Rossiiskoi Federatsii [Collection of Legislation of the Russian Federation], 3 January 2005, No 1 (Part 1), p. 41; Federal Law of 18 July 2009, No 190FZ 'On Credit Cooperation' // Sobranie zakonodatel'stva Rossiiskoi Federatsii [Collection of Legislation of the Russian Federation], 20 July 2009, No 29, p. 3627; Federal Law of 2 July 2010, No 151FZ 'On Micro-Financial Activity and Micro-Financial Institutions' // Sobranie zakonodatel'stva Rossiiskoi Federatsii [Collection of Legislation of the Russian Federation], 5 July 2010, No 27, p. 3435.
(NYSE) and the National Association of Securities Dealers, Inc. (NASD).

The NYSE was established at market participants' own initiative. They also set standards and guidelines for their own activities. As NYSE members cared about the reputation of their organization, their services were in greater demand among securities owners and other clients than those provided by the NASD.

By contrast, the NASD was created with the active participation of the State (the Maloney Act of 1938), and its members did not take part in the development of standards and guidelines. Standards and rules, usually referring to the normative acts of the state regulator, were mutually agreed upon by the management of the self-regulating organization and the state regulator. Thus, the NASD was deprived of one of the most important advantages of self-regulation - participation in the development of standards and guidelines, so helpful in getting to a higher level of observance with those standards and guidelines.

If the above provisions of the Bank of Russia's Draft Law should indeed come into force, safe-regulating organizations may easily find themselves in a situation similar to that of the NASD, which then will further be aggravated by the fact that the state regulator will apparently have the right to decide whether or not the candidacy of a person nominated to head one or other self-regulating organization should be accepted (this is discussed in more detail later in our overview).

The second idea of the Bank of Russia's Draft Law that can harm the interests of self-regulating organizations operating in financial markets and, correspondingly, the interests of their members, is the idea that the supervisory function of those organizations should be curbed.

Apart from the two afore-mentioned components of self-regulation (the function of setting of standards and guidelines for self-regulating organizations and the function of supervision over the observance thereof ${ }^{2}$ ), the Bank of Russia has established a third component - supervision over the observance of the federal laws which regulate financial market activities, normative legal acts of the Russian Federation, and normative legal acts issued by the Bank of Russia (Articles 6 and 7).

It should be noted that, at present, the constituent documents of some self-regulating organizations specify that one of their powers is to supervise the activity of their members ${ }^{3}$.

2 In the draft federal law submitted by the Bank of Russia, this component is referred to as monitoring the observance of standards, guidelines and the Federal Law 'On Self-Regulating Organizations in the Field of Financial Markets'.

3 See, for example, sub-item ' $\mathrm{e}$ ' of item 2.1 of the Charter of the National Association of Stock Market Participants and paragraph 4, item 2.2 of the Charter of Registars, Transfer Agents and Depositories. 
However, while proposing to legislatively establish this additional component of self-regulation, the Bank of Russia at the same time stipulates that a self-regulating organization should have the right to supervise the activity of its members only if the corresponding powers have been delegated to it by the Bank of Russia. The procedure for delegating the afore-said powers, as well as the reasons and the procedure for their cancellation, is to be established by the Bank of Russia on an individual basis for each of the types of self-regulating organizations (the powers delegated to same-type organizations should be absolutely equal). The fact of the supervisory powers being delegated to self-regulating organizations should not imply that the Bank of Russia itself has lost such powers.

In the event when the Bank of Russia has delegated to a self-regulating organization the powers to receive accounting and other reports from its members; to conduct personnel certification with regard to its CEOs, members and personnel; and to participate - via its representatives - in the supervision of the activity of its members, carried out by the Bank of Russia and state authorities, these functions should also be performed by the afore-said self-regulating organization.

Thus the Bank of Russia intends to create a new system for regulating the activity of self-regulating organizations in the field of financial markets, the upshot of which will be a significantly increased role of the state regulator. According to the Draft Law, the state regulator will then be free to unilaterally determine the scope of its own participation in the regulatory process. The unfettered discretion given to the state regulator may significantly undermine the interests of self-regulating organizations and their members, because the Draft Law lacks any formal guarantee that the Bank of Russia should permit such organizations to adequately participate in the process of setting standards and guidelines or in monitoring compliance therewith.

Unlike the existing model of self-regulation in the field of financial markets, which implies that self-regulating organizations should be voluntary associations, the Draft Law submitted by the Bank of Russia stipulates that membership in such organizations should be mandatory (Article 11).

At the same time, the Draft Law does not eliminate the licensing of activity, although the licensing of activity makes sense only when membership in a self-regulating organization is voluntary.

According to Article 4 of the Draft Law, the following types of self-regulating organizations can be created in the field of financial markets: (1) SROs of brokers; (2) SROs of dealers; (3) SROs of managers; (4) SROs of depositories; (5) SROs of registars; (6) SROs of jointstock investment funds, mutual funds, investment funds' asset managers and non-governmental pension funds; (7) SROs of specialized depositories; (8) SROs of non-governmental pension funds; (9) SROs of the following insurance subjects: insurance organizations, insurance brokers, mutual insurance societies; (10) SROs of micro-financial organizations; (11) SROs of credit cooperatives; (12) SROs of housing savings cooperatives; (13) SROs of credit history bureaus ${ }^{1}$.

At present, mandatory membership is established only for credit cooperatives, with the exception of second-level cooperatives ${ }^{2}$.

Maybe, the Bank of Russia's proposal to the effect that membership in self-regulating organizations operating in the field of financial markets should be made mandatory was motivated by the Bank's desire to safeguard the interests of securities owners and other clients of financial institutions, because this measure is designed to make it possible to establish additional control over the activity of such organizations. However, past experience indicates that sometimes such mandatory double control (licensing and self-regulation), if introduced in conjunction with the extended powers of the state regulator, may not necessarily be in the best interests of financial institution clients.

It goes without saying that financial institution clients are interested not only in the security of their interests, but also - and primarily - in obtaining some profit. The simultaneous presence of several voluntary self-regulating organizations promotes competition and is conductive to establishing better standards and guidelines, intended to be more attractive to potential clients. In such a situation, potential clients are able to pick and choose among the differing financial institutions - members of one or other self-regulating organization.

The Draft Law also stipulates that, in order to get registered, a self-regulating organization uniting financial institutions of the same type should comprise at least $30 \%$ of the total number of financial institutions engaged in that type of activity, not counting its associated members ${ }^{3}$.

1 Federal Law of 30 December 2004, No 218-FZ 'On Credit Histories' (see Sobranie zakonodatel'stva Rossiiskoi Federatsii [Collection of Legislation of the Russian Federation], 3 January 2005, No 1 (Part 1), p. 44) does not envisage the establishment of self-regulating organizations of credit history bureaus. However, this does not imply that such organizations may not be established in accordance with the 2007 framework Law 'On Self-Regulating Organizations.

2 Item 1 of Article 35 of Federal Law of 18 July 2009, No 190FZ 'On Credit Cooperation' // Sobranie zakonodatel'stva Rossiiskoi Federatsii [Collection of Legislation of the Russian Federation], 20 July 2009, No 29, p. 3627.

3 On associated membership, see Article 15 of the Bank of Russia's Draft Law. 
According to the Draft Law, a financial institution should be endowed with the right to be a member of only one self-regulating organization of one or other specific type. If a financial institution is engaged in different types of activity, it should have the right to become a member of several self-regulating organizations of different types, or of a self-regulating organization comprising several self-regulating organizations of different types. In the latter case, a self-regulating organization can be established, provided that it will comprise no less than $30 \%$ of the total number of financial institutions engaged in each type of activity.

Therefore, this provision of the Draft Law effectively means that the number of same-type self-regulating organization should be limited to three.

At present, the existing framework rule stipulates that, in order to be granted the status of self-regulating organization, a not-for-profit organization should comprise no less than one hundred subjects of specific professional activity (or no less than twenty-five subjects of entrepreneurial activity), unless otherwise provided by federal legislation ${ }^{1}$. The laws regulating the activity of those self-regulating organizations in the field of financial markets, to which the 2007 framework Law on Self-Regulating Organizations does not apply (SROs of pension funds and the organizations contracted by them to manage pension accounts; SROs of asset managers; SROs of housing savings cooperatives), do not specify the minimum required number of members for a self-regulating organization to be registered. The only exception is represented by self-regulating organizations of professional securities market participants (the minimum required number of members is ten). Thus, at present the number of same-type selfregulating organizations is not limited by law.

Also, the Bank of Russia intends to introduce a procedure whereby it will have the right to decide whether or not the head of a self-regulating organization meets the established professional qualification requirements. Furthermore, the Daft Law stipulates that the Bank of Russia should have the right to decide whether or not the candidacy of a person nominated

1 Sub-item 1, Item 3 of Article 3 of Federal Law of 1 December 2007, No 315-FZ 'On Self-Regulating Organizations'. to become head one or other self-regulating organization should be accepted (Article 29).

At present, the issue of appointing and dismissing the head of a self-regulating organization belongs to the competence of the corresponding body of that organization.

The Draft Law establishes that the heads of selfregulating organizations (or other persons representing their interests) and the council of self-regulating organizations (in the person of its chairperson), which they have the right to create, selecting it from the ranks of their CEOs, should be entitled to represent, on a consultative basis, the interests of the said selfregulating organizations to the Bank of Russia.

However, according to the Draft Law, all the rights and duties of the afore-said representatives to the Bank of Russia, including issues pertaining to the subject of activity of the self-regulating organizations whose interests they represent, should be determined by the Bank of Russia (Article 35).

Representation of its members interests vis-à-vis the RF federal authorities, bodies of state authority of Russian Federation subjects and local self-government bodies is one of the main functions of any self-regulating organization. Therefore, the state regulator's participation in appointing representatives of the interests of the organizations supervised by the said regulator, in this case the heads of self-regulating organizations, may turn out to be harmful to the interests of such organizations.

As far as the current situation of self-regulating enterprises is concerned, the following observations may be offered. One can say that, so far, the appointment of a new state regulator has had no effect on the procedure for regulating the activity of self-regulating organizations in the field of financial markets. Financial market participants continue to enjoy significant independence in regulating their own activity.

However, if the Bank of Russia's Draft Law 'On SelfRegulating Organizations in the Field of Financial Markets' is enacted into law, the influence of the state regulator and the load on financial market participants (financial institutions) will sharply increase. Moreover, it is not impossible that the very essence of self-regulating organizations will disappear into thin air, in spite of the preservation of their formal status. 